\title{
APPLICATION OF A SEMIAUTOMATIC CLASSIFIER FOR MODIC AND DISK HERNIA CHANGES IN MAGNETIC RESONANCE
}

\author{
APLICAÇÃO DE CLASSIFICADOR SEMIAUTOMÁTICO PARA ALTERAÇÕES MODIC \\ E HÉRNIA DE DISCO EM RESSONÂNCIA MAGNÉTICA
}

\author{
APLICACIÓN DE CLASIFICADOR SEMIAUTOMÁTICO DE CAMBIOS MODIC \\ Y HERNIA DE DISCO EN RESONANCIA MAGNÉTICA
}

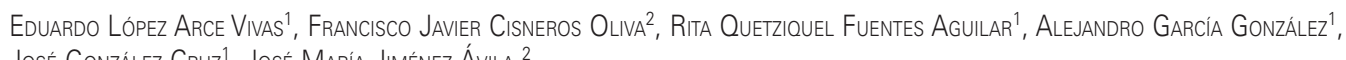
José González Cruz', José María Jiménez Ávila ${ }^{2}$

\begin{abstract}
Objective: Early detection of degenerative changes in lumbar intervertebral disc by magnetic resonance imaging in a semiautomatic classifier for prevention of degenerative disease. Method: MRIs were selected with a diagnosis of degenerative disc disease or back pain from January to May 2014, with a sample of 23 patients and a total of 170 disks evaluated by sagittal T2 MRI image, first evaluated by a specialist physician in training and them were introduced into the software, being the results compared. Results: One hundred and fifteen discs were evaluated by a programmed semiautomatic classifier to identify MODIC changes and hernia, which produced results "normal or MODIC" and "normal or abnormal", respectively. With a total of 230 readings, of which 141 were correct, 84 were reading errors and 10 readings were undiagnosed, the semiautomatic classifier is a useful tool for early diagnosis or established disease and is easy to apply because of the speed and ease of use; however, at this early stage of development, software is inferior to clinical observations and the results were from around 65\% to 60\% certainty for MODIC rating and 61\% to 58\% for disc herniation, compared with clinical evaluations. Conclusion: The comparative results between the two doctors were 94 consistent results and only 21 errors, which represents $81 \%$ certainty.
\end{abstract}

Keywords: Intervertebral disc; Hernia; Low back pain; Magnetic resonance imaging.

\section{RESUMO}

Objetivo: Determinação precoce de alterações degenerativas de disco intervertebral lombar por ressonância magnética em classificador semi- automático para prevenção da doença degenerativa. Métodos: Foram selecionadas ressonâncias magnéticas com diagnóstico de doença degenerativa do disco ou lombalgia de janeiro a maio de 2014, com uma amostra de 23 pacientes e um total de 170 discos avaliados por RM T2 em corte sagital, examinadas primeiro por um médico especialista em treinamento, e depois foram introduzidas no software e os resultados obtidos foram comparados entre si. Cento e quinze discos foram submetidos à avaliação por um classificador semiautomático programado para identificar alterações MODIC e hérnia, o que produziu resultados "normal ou MODIC" e "normal ou anormal", respectivamente. Resultados: Com um total de 230 leituras, das quais 141 estavam corretas, 84 foram erros de leitura e 10 leituras foram sem diagnóstico, o classificador semiautomático é uma ferramenta útil para o diagnóstico precoce ou da doença estabelecida e é fácil de aplicar, devido à rapidez e facilidade de uso; contudo, nesta fase inicial de desenvolvimento, o software é inferior às observações clínicas e os resultados foram de cerca de 65\% a 60\% de certeza para a classificação MODIC e de 61\% a 58\% para hérnia de disco, em comparação com a avaliação clínica. Conclusão: Os resultados comparativos entre os dois médicos foram 94 resultados congruentes e apenas 21 erros, o que representa $81 \%$ de certeza.

Descritores: Disco intervertebral; Hérnia; Dor lombar; Imagem por ressonância magnética.

\section{RESUMEN}

Objetivo: Determinación temprana de cambios degenerativos de disco intervertebral lumbar por resonancia magnética, mediante clasificador semiautomático para la prevención de enfermedad degenerativa. Métodos: Se seleccionaron resonancias magnéticas con diagnóstico de enfermedad degenerativa de disco o lumbalgia de enero hasta mayo de 2014, con una muestra de 23 pacientes y un total de 170 discos valorados en corte sagital de RNM en T2, las cuales se examinaron primero por médico especialista en formación, y que luego fueron introducidas en el software, siendo los resultados obtenidos comparados entre sí. Ciento quince discos fueron sometidos a valoración por un clasificador semiautomático programado para identificar cambios MODIC y hernia que produjo resultados "normal o MODIC" y "normal o anormal", respectivamente. Resultados: Con un total de 230 lecturas, de las cuales 141 fueron correctas en general, 84 fueron errores de lectura y 10 fueron lecturas sin diagnóstico, el clasificador semiautomático es una herramienta útil para el diagnóstico precoz o de enfermedad instaurada, así como fácil de aplicar debido a su rapidez y facilidad de uso; sin embargo, en esta primera etapa del desarrollo, el software es inferior a la apreciación clínica ya que los resultados fueron de alrededor de 65\%-60\% de certeza para clasificación MODIC y 61\%-58\% para hernia de disco, en comparación con la evaluación clínica. Conclusión: Los resultados comparativos entre los dos médicos fueron 94 resultados congruentes entre médicos y solo 21 errores, lo que representa el $81 \%$ de certeza.

Descriptores: Disco intervertebral; Hernia; Dolor de la región lumbar; Imagen por resonancia magnética.

1. Campus Guadalajara, Av. General Ramón Corona \# 2514, CP: 45201, Zapopan, Jalisco, México.

2. Servicio de Traumatología y Ortopedia; Centro Médico Nacional de Occidente; Avenida Belisario Domínguez 1000, Belisario Domínguez, 44329 Guadalajara, Jalisco, México.

Study conducted at the Centro Médico Nacional de Occidente, Unidad Médica de Alta Especialidad, Servicio de Ortopedia y Traumatología, Modulo de Columna, Guadalajara, Jalisco, México.

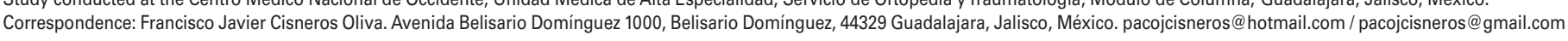




\section{INTRODUCTION}

The origin of diseases of the lumbar spine, and herniated discs in particular, is still a matter of debate in the scientific world, although a multifactorial etiology that includes genetic, degenerative, biochemical, medical, traumatic, and psychosocial factors is accepted. ${ }^{1}$

Until the late twentieth century, it was believed that low back pain was mostly due to overexertion of the muscles and organic changes such as arthrosis, scoliosis, and disc herniation, but scientific studies conducted over the last twenty years have shown that most organic changes of the spine are irrelevant, and do not correlate with the presence of pain, and $80-85 \%$ of cases of low back pain are diagnosed as unspecific pathologies due to the absence of any relationship between the results of complementary examinations and the patient's clinical history. ${ }^{1}$

Degenerative intervertebral disc disease is a common cause of low back pain among spine pathologies, and can be classified into three types based on its duration: Acute, if the symptoms last less than six weeks; Subacute, if they last between six and twelve weeks; and Chronic, when the profile persists for more than 12 weeks. ${ }^{2}$ Regarding symptoms, in the acute type, non-specific low back pain is triggered by inadequate functioning of the musculature that supports the anatomical region of reference, causing persistent activation of the nerve fibers, which in turn, triggers pain, muscular contractions, and inflammation and causes them to persist. In the subacute type, this mechanism remains active and can cause persistent changes in the medullary neurons, resulting in continued pain, inflammation, and contractions, even when the problem that initially caused them is resolved. In the chronic type, nerve changes are added to the muscular and psychosocial factors, evolving into a vicious cycle that makes spontaneous recovery difficult for the affected person. Physical inactivity results in a loss of muscle coordination and strength and, in the medium term, the appearance of atrophy and worsening of the initial clinical profile. ${ }^{1}$ Subsequent physical disability can sometimes be totally debilitating because it can lead to neurological impairment in our experience, which leads to problems of absenteeism or permanent inability to perform daily activities. This is because the diagnosis is based on two-dimensional images and even today remains very subjective, depending on the evaluator, which could lead to its diagnosis being made only in an advanced phase of the disease, when the only treatment is sometimes extraction of the disc and intervertebral fusion as a palliative analgesic measure. According to different authors cited, ${ }^{3} 5 \%$ to $15 \%$ of patients with an unfavorable prognosis experience recurrence or chronic postoperative pain. Determining incapacity to work in a patient who is feigning symptoms cannot always be done accurately, because the clinical parameters provided by the patient are subjective, based mainly on pain, sensory disturbances, and changes in muscle strength of one or more limbs. ${ }^{4}$ The need for programs to promote health care and change work habits that promote the development and persistence of pathologies like degenerative disc disease is clear, based on statistics that state that in $58.7 \%$ of people who claim to suffer or to have suffered from low back pain, the onset of symptoms follows extreme physical exertion to lift objects. ${ }^{2}$ For this reason, we try to identify degenerative changes in the intervertebral disc early, in order to carry out conservative therapeutic intervention that can prolong the functional life of the degenerating disc.

Degenerative disc disease has become a global health problem, and various occupational health reports show an increase in the incidence of this pathology, associated with low back pain as its main symptom, and inability to perform physical activity, either in the home or at work, as its main outcome, with the latter representing exorbitant social security costs for companies and/or those affected.

In 2013, the research team of Dr. Lozano et al ${ }^{5}$ conducted a literature review of Occupational Health in which they determined Years Lived with Disability (YLD) associated with diseases. They found that low back pain was in first place among males, with 394.682 thousand years of life associated with disability, and in second place among females, with 356.554 thousand years of life associated with disability, in a 2010 report on the construction of disability weighting factors, based on a survey of more than 15,000 households in five countries and an electronic survey of 16,328 participants in 175 countries. The YLDs were estimated based on prevalent cases of the 1160 complications studied. The sources that Mexico contributed to the international study included hospital discharge registers, the 1987 and 1994 national health surveys, the 2000 and 2006 national health and nutrition surveys, the 1988 and 1999 national nutrition surveys, epidemiological surveillance records regarding mandatory reportable diseases, and other epidemiological studies that the specialists included in systematic reviews. ${ }^{5}$

Between $70 \%$ and $85 \%$ of the population suffer from low back pain at some time during their lives. Low back pain is the primary cause of disability in people under 50 years of age. Potential causes of low back pain include intervertebral discs, facets, neural structures, vertebrae, muscles, ligaments, and fascias. ${ }^{6}$

Mechanical, traumatic, nutritional, and genetic factors also combine to play an important role in the evolution of disc degeneration. ${ }^{7}$

Acute low back pain is more common than the progressive chronic pain that interferes with functional capacity. This latter condition is associated with other non-changeable risk factors like age and genetics, and changeable factors which include smoking, some forms of physical activity, and obesity. ${ }^{8}$

Regular physical activity can reduce or increase the risk of disc degeneration depending on how intense or prolonged it is. ${ }^{9}$

Smoking probably hinders the transport of metabolites within the disc, increasing the risk of degeneration. The importance of metabolic and mechanical damage as initiators of disc degeneration is difficult to define, due to the interaction between them combined with genetic influence. ${ }^{9}$

Both weight gain and the abnormal geometric weight distribution characteristic of truncal obesity increase the forces supported by the spine ${ }^{8}$ related to an increase in axial load on the spine and a progressive migration of the center of gravity farther to the anterior part of the spine. ${ }^{10}$ Obesity is a risk factor for multiple illnesses, among them lower back pain and complications during the surgical procedures that surround it. ${ }^{11}$

Genetic factors are consistently described in animal models, with degenerative disc disease at an early age in cases of familial osteoarthritis and stenosis of the lumbar canal. ${ }^{12}$

Magnetic resonance imaging is the most important diagnostic method for clinical diagnosis of intervertebral disc disease. The characteristic signal is usually in disc $\mathrm{T} 2$, which best reflects changes in age and/or degeneration, ${ }^{13}$ primarily in sagittal section.

In reality, degenerative disc disease can be classified, albeit subjectively (at the observer's discretion) based on changes in the immediate upper and immediate lower platforms of each disc, which according to the Modic classification, are common findings and represent distinct histological stages in the subchondral bone marrow, considered to be part of degenerative bone disease. In which we find Modic I: T1 - Reduction in signal; T2 - Increase in signal; Microfractures, edema, and vascularized fibrogranular tissue. Modic II: T1 - Increase in signal; T2 - Increase in signal; Fatty infiltration and demineralization of the spongy subchondral bone. Modic III: T1 - Reduction in signal; T2 - Reduction in signal. Bone sclerosis, regeneration with subchondral bone remodeling. ${ }^{14}$

Injury to the lumbar disc, where the nucleus pulposus emerges through the annulus, is classified as a protrusion or contained hernia, extrusion and sequestration, or hernia, ${ }^{15}$ and may be described as central, posterolateral, lateral, foraminal, or extraforaminal. ${ }^{16}$

The concept of occupational injury alludes to any change in health related to, caused by, or complicated by working conditions. There are various types of occupational injury: work-related accidents, professional illnesses associated with or aggravated by work, and others. Low back pain and lumbar spine diseases are not included in the profile of professional illnesses, but they meet the legal requirements to be considered occupational injuries, since they are work-related accidents. ${ }^{4}$ 
Degenerative intervertebral disc disease is a health problem of increasing prevalence. In Spain, it is estimated that $80 \%$ of the population is affected by low back pain at some time during their lives (Estudio EPISER, 2001). ${ }^{1}$ In our environment, where a person's development is defined by their social sphere, represented by work, school, and family, and where in most cases, surgery is the method for temporary resolution, it is important to try to define a timely approach to the pathology. Early detection will help us to perform physical therapy and rehabilitation to prolong the life of the degenerating disc, thereby reducing the social limitations of the patient and decreasing the costs associated with occupational disability. Recovery from low back pain takes from one to two months in $90-95 \%$ of cases. The remaining $5-10 \%$ of cases that become chronic are responsible for $85-90 \%$ of the costs associated with this pathology. The most alarming aspect is that these data, far from decreasing, are increasing not only in Spain, but also but in neighboring countries. As an example, recent figures from Germany report direct costs incurred from low back pain of $€ 7,000 /$ person, with absenteeism accounting for $75 \%$ of the total costs of temporary disability (TD) in that country.

According to the 2010 census, there were $7,350,682$ inhabitants in Jalisco, 3,043,656 of whom were entitled to benefits from the Mexican Social Security Institute. Workers and beneficiaries represented $41.4 \%$ of the population of Jalisco. ${ }^{17}$ Care of degenerative diseases was in second place, outranked only by care of traumatic conditions, with the highest risk group above sixty years of age, with a high priority for preventative care. The average age was 48 years, a group that is more susceptible to traffic and work-related accidents. ${ }^{18}$

Hospital admissions to the Centro Médico Nacional de Occidente were studied. In the Orthopedics and Traumatology Service, 4,713 patients ( $45 \%$ female and $55 \%$ male) were treated, predominantly adults with an average age of 48.9 years, standard deviation of 16.8 years, with a marked increase is hospital costs during the months with the highest prevalence - January, February, and April, and a drop in July, October, and December. The total hospital costs were estimated at $\$ 85,565,288.00$, trauma accounting for $\$ 40,404,477.00$ and degenerative processes $\$ 21,866,815.00$. The months with the highest spending were April at $\$ 11,072,683.00$, December at $\$ 8,423,773.00$, and February at $\$ 8,154,152.00$. July recorded the lowest spending at $\$ 4,874,261.00$. $^{7}$

\section{MATERIAL}

Patients diagnosed with degenerative disorders of the lumbar spine (narrow lumbar canal, herniated disc, spondyloarthrosis, spondylolisthesis) and low back pain under observation, who underwent Lumbar Magnetic Resonance imaging as a complementary diagnostic procedure, during the period January to May 2014, at the Hospital de Especialidades Centro Médico Nacional de Occidente, and who met the inclusion criteria.

\section{Study group}

Cases: Patients diagnosed with degenerative disturbances of the lumbar spine (narrow lumbar canal, herniated disc, spondyloarthrosis, spondylolisthesis) and low back pain under observation, who underwent Lumbar Magnetic Resonance as a complementary diagnostic procedure

Controls: Patients diagnosed with degenerative disturbances of the lumbar spine (narrow lumbar canal, herniated disc, spondyloarthrosis, and spondylolisthesis) and low back pain under observation, who underwent Lumbar Magnetic Resonance as a complementary diagnostic procedure, which was analyzed by the semiautomated classification system for detection of MODIC changes and disc herniation.

\section{METHOD}

We obtained a sample of 23 patients; 8 were men and 13 were women. Their ages ranged from the teens to the seventies, with the highest incidence in men aged between 50 and 60 years and women aged between 60 and 70 years.
Each of the discs from L1-L2 to L5-S1, 115 in total, was classified in the traditional way, based on the MRIs, by an observer. Using the MODIC classification as reference, early stage MODIC II changes were found to be more prevalent in the women, as compared to a greater incidence of MODIC III changes in the men. The classification for disc hernia bulging, extrusion, and protrusion was used. There was a greater incidence of disc protrusion in the men, as opposed to the women, in whom bulging and protrusion had the same incidence. The fact that there were patients with multilevel involvement should also be taken into account.

Several classifiers were tested to determine which were the best for defining disc disease from the magnetic resonance images. These were divided into groups, as follows: linear - Linear Discriminant Analysis (LDA) and Support Vector Machines (SVM); probabilistic - Naive Bayes (NB) and k-Nearest Neighbor (KNN), and artificial intelligence - Adaptive Neuro-Fuzzy Inference System (ANFIS). KNN was selected for MODIC classification and SVM for disc herniation, with classification precision of $96.91 \%$ and $85.24 \%$ respectively. The decision was made after computer analysis and classification with the table of contents.

Images in JPG format with dimensions of 1019x680 were then taken, in the format provided by the native magnetic resonance program. These were subsequently submitted for classification using the method proposed and developed for evaluation of intervertebral degenerative disc disease. Once the image had been selected in the software, the number of discs to be classified was selected. (Figure 1) Then, using the cursor, a central mark was drawn from the most cephalic to the most caudal disc. (Figure 2) Once selected, the image was segmented by drawing two parabolas, delimiting the discs to be studied. (Figure 3A) These were then segmented (Figure $3 \mathrm{~B}$ ) and analyzed by the application created. The results were delivered as Normal or Abnormal in terms of herniated disc disease and MODIC or Normal in terms of the classification of degenerative disc disease. (Figure 4)

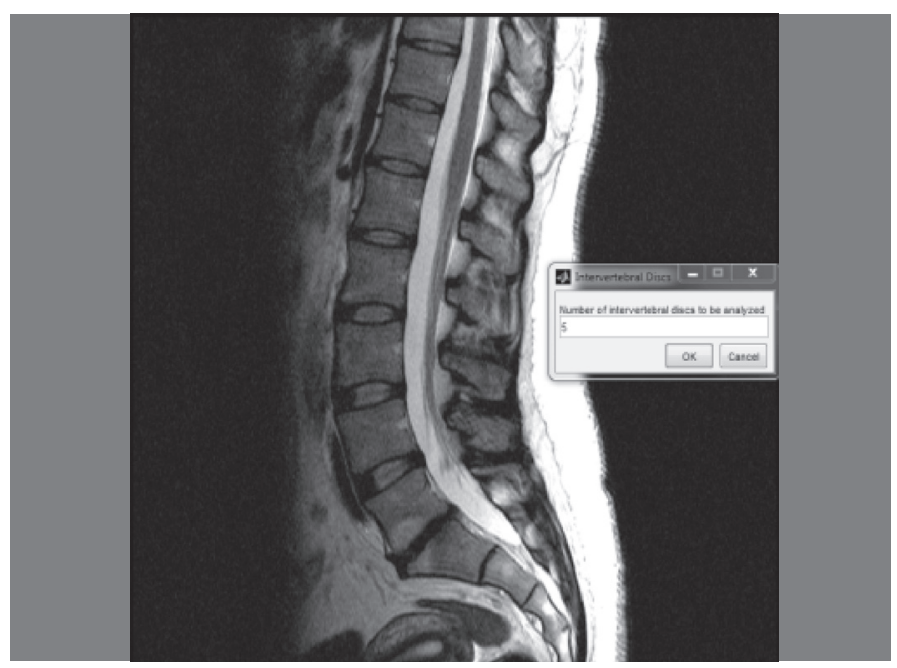

Figure 1. The number of discs to be analyzed is selected numerically.

\section{RESULTS}

The readings of a total of 115 discs, previously classified by an orthopedic doctor in training, were compared with readings made by the semiautomatic classifier both for disk disease, using classifications of MODIC or Normal, and for disc herniation, using classifications of either Normal or Abnormal. A total of 230 readings were performed, producing 141 successful matches, 84 reading mismatches, and 10 readings without a diagnosis. Regarding the classification of degenerative disc disease, there were 70 successful matches and 45 mismatches at the time of comparison of the results from the doctor and the classifier, in addition to 5 readings with no diagnosis made by the classifier. A second comparison 


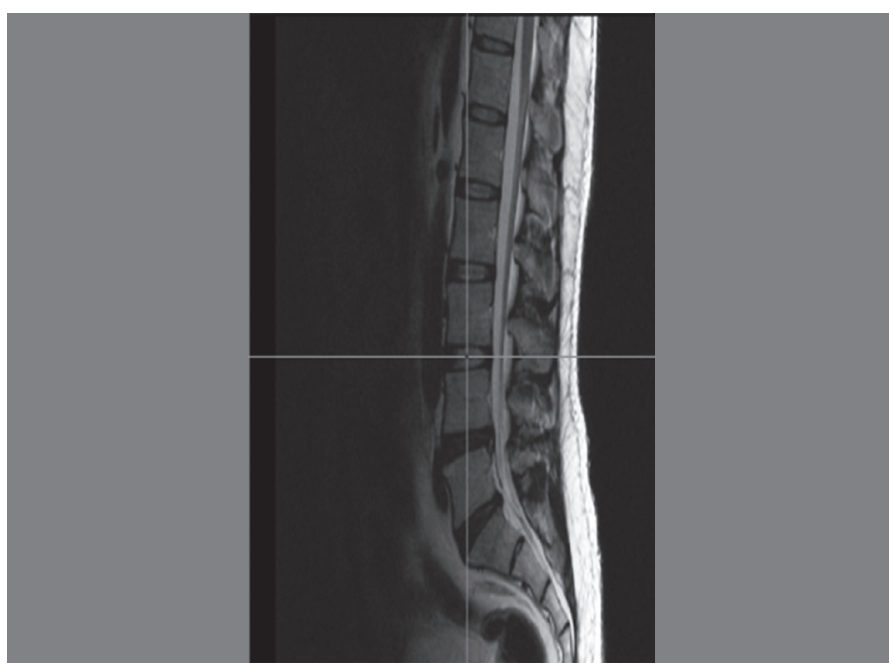

Figure 2. Selected centrally by means using the cursor in cephalocaudal order and according to the number of disks previously selected.

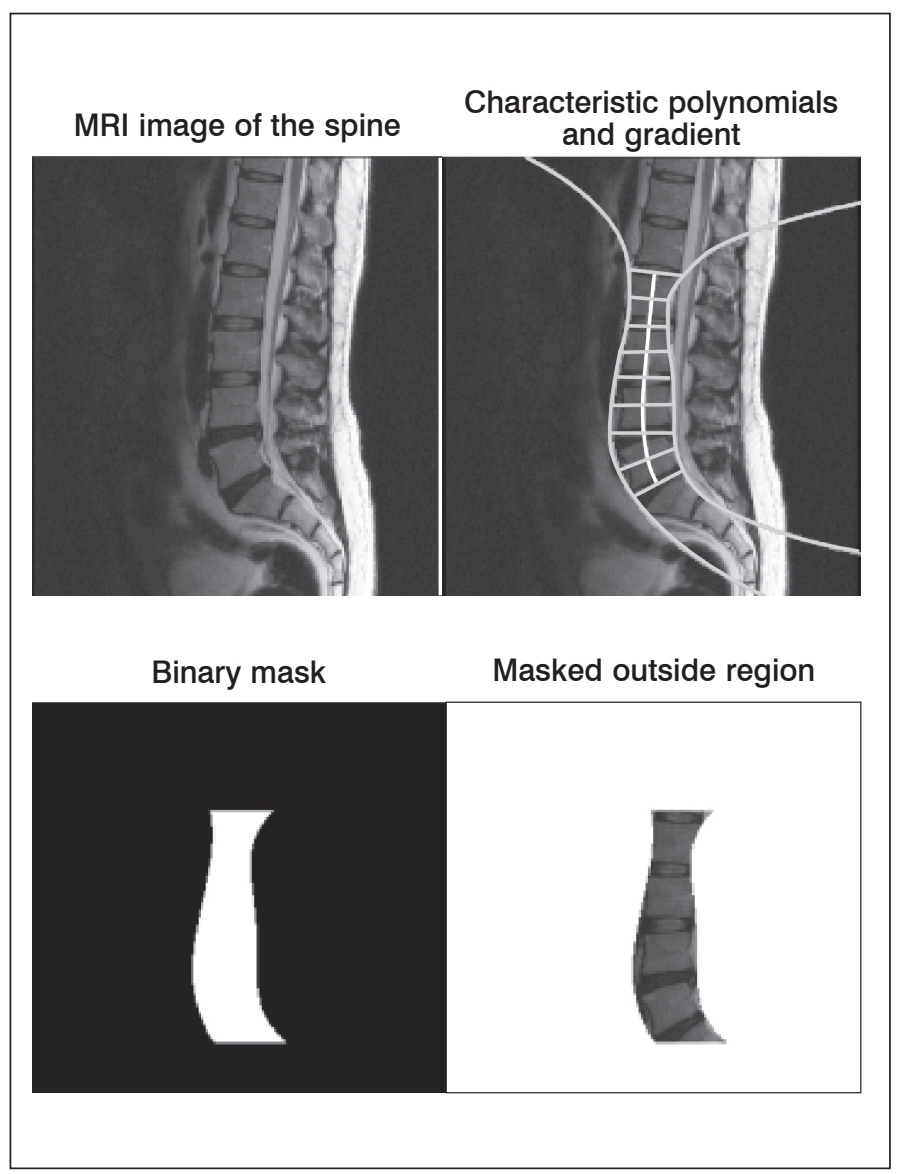

Figure 3. The image is observed before the process (3.0) after performing the steps, 2 parabolas are formed (3.1) in the magnetic resonance image, therefore the number of discs selected will be fragmented (3.2) obtaining a fragment which will be analyzed.

was conducted with a doctor specializing in the spine, obtaining 75 matches between the application and the clinical readings, 40 mismatches, and 5 with no reading.

In terms of disc herniation, there were 71 matches, 39 mismatches, and 5 undiagnosed readings in the comparison between the doctor in training and classifier results. The comparison of hernia disease readings between experience and technology yielded 67 matches, 43 mismatches, and 5 with no reading.

$$
\begin{aligned}
& \text { 'L01 - L02 ' } \\
& \text { 'L02 - L03 ' } \\
& \text { 'L03 - L04 ' } \\
& \text { ' L04 - L05 ' } \\
& \text { 'L05 - S01 ' }
\end{aligned}
$$

' Normal '
' Normal '
' Normal '
' Modic '
' Normal '

' Normal '

' Normal '

' Normal '

' Abnormal '

'Abnormal '
Figure 4. Format in which the results are delivered after processing by the software.

The results were analyzed, and a diagnostic congruence was observed between the classical (clinical) diagnostic method and the method proposed by this study of $60 \%$ certainty for the diagnosis of MODIC changes and $61 \%$ certainty for the diagnosis of disc herniation of all degrees, with the doctor in training. As regards the medical specialist, the comparison with the semiautomatic classifier yielded $65 \%$ diagnostic certainty for MODIC changes and $58 \%$ for disc herniation.

Due to the close similarity of results between experienced doctors and doctors in training with respect to the semiautomatic classifier, it was decided that a third comparison should be conducted between doctors, with the following results: for the MODIC classification of degeneration, there were 94 matches between the doctors and only 21 mismatches in which the diagnosis did not coincide, while for hernia disease, there were 77 matches and 33 mismatches.

This corresponds to a diagnostic congruence of $82 \%$ between the two doctors for the diagnosis of MODIC changes in magnetic resonance images, and $67 \%$ of diagnostic congruence between the two doctors for disc herniation.

The levels where differences were found varied, without any dependency or influence from the level of the disc affected, although the 10 readings that were provided by the classifier were always at the lower levels, L4-L5 and L5-S1.

Among the errors found, there were 20 cases in which the level, classified as an affected disc by the computer equipment, had previously been classified as normal by the doctor, 20 cases where the doctor classified them as MODIC and the software classified them as normal, and three cases where the diagnostic program did not provide a diagnosis which were classified as MODIC by the doctor. The remaining two were classified as normal.

As for the hernias, 24 cases were classified by the program as having disc involvement of some sort, while the doctor classified them as normal. In 11 cases, the human diagnosis was herniation and the classifier recognized them as having no type of hernia involvement. Of the cases with no reading by the program, two were diagnosed by the doctor as herniated and three as normal.

\section{DISCUSSION}

Clinical observation by medical specialists, in this case using magnetic resonance images of the lumbar spine, for the classification and identification of findings has become the best method for diagnosis and definition of degenerative lumbar disk disease and herniated discs, classifying them based on already established parameters such as MODIC changes and herniated disc classifications. However, even with defined parameters there is a wide margin of variability between the interpretations of medical specialists, and despite significant and innovative technological advances, there is still no early, rapid, and accurate classifier for the identification of degenerative changes of lumbar disc disease. An approximation of these three aspects is achieved with the new diagnostic method presented in this study, however, the development of new versions must continue to narrow the variation gap between interpretations, and achieve diagnostic certainty in future versions of the software. 


\section{CONCLUSION}

The semiautomatic classifier is a useful tool for diagnosis of earlystage or established disease because it is easy to apply, rapid, and easy to understand. However, in this first stage of development of the software, it is still not as effective as clinical diagnosis given that the results were in the range of $60-65 \%$ certainty for the MODIC classification and $58-61 \%$ for herniated discs, as compared with clinical experience. The comparison between the two doctors yielded 94 matches and only 21 errors, which translates into 94\% certainty for MODIC changes and $67 \%$ for herniated disc disease. This leads us to consider new proposals to attain the same effectiveness of diagnostic certainty with the semiautomatic classifier as that achieved by doctors.

All authors declare no potential conflict of interest concerning this article.

\section{REFERENCES}

1. Vicente-Herrero MT, Ramírez-Iñiguez MT, Capdevila-García LM, López-González AA, Terradillos-García MJ, Aguilar-Jiménez E, et al. Las enfermedades de la columna lumbar y su relación con el trabajo en España. Seguridad y Medio Ambiente. 2012:126:1-70.

2. Saldívar-González AH, Cruz-Torres DL, Serviere-Zaragoza L, Vázquez-Nava F, Joffre-Velázquez VManuel. Lumbalgia en trabajadores. Rev Med IMSS. 2003; 41(3):203-9.

3. Lee JK, Amorosa L, Cho SK, Weidenbaum M, Kim Y. Recurrent lumbar disk herniation. J Am Acad Orthop Surg. 2010;18(6):327-37.

4. Boleaga-Durán B. Conceptos básicos de la enfermedad lumbar degenerativa. An Radiol Mex. 2007;6(1):51-61.

5. Lozano R, Gómez-Dantés H, Garrido-Latorre F Jiménez-Corona A Campuzano-Rincón $J C$, Franco-Marina $F$, et al. Burden of disease, injuries, risk factors and challenges for the health system in Mexico]. Salud Publica Mex. 2013;55(6):580-94.

6. Biyani A, Andersson GB. Low back pain: pathophysiology and management. J Am Acad Orthop Surg. 2004;12(2):106-15

7. Modic MT, Ross JS. Lumbar degenerative disk disease. Radiology. 2007;245(1):43-61.

8. Avila-Ramírez J, Reyes-Rodríguez VA. La obesidad y el sobrepeso, su efecto sobre la columna lumbar. Rev Mex Neuroci. 2009:10(3):220-3.

9. Adams MA, Freeman BJ, Morrison HP, Nelson IW, Dolan P. Mechanical initiation of intervertebral disc degeneration. Spine (Phila Pa 1976). 2000;25(13):1625-36.

10. White AA, Panjabi MM. Clinical Biomechanics of the Spine. 2nd ed. Philadelphia: Lippincott; 1990.

11. Espinosa de los Monteros F. Influencia de la obesidad sobre los resultados de una

cirugía de columna en pacientes con padecimientos degenerativos. Coluna/Columna.2011; $1(3): 52-9$

12. Kresina TF, Malemud CJ, Moskowitz RW. Analysis of osteoarthritic cartilage using monoclonal antibodies reactive with rabbit proteoglycan. Arthritis Rheum. 1986;29(7):863-71.

13. Pfirrmann CW, Metzdorf A, Zanetti M, Hodler J, Boos N. Magnetic resonance classification of lumbar intervertebral disc degeneration. Spine (Phila Pa 1976). 2001;26(17):1873-8

14. Domínguez-Gasca LG, Domínguez-Carrillo G. Cambios tipo Modic en la resonancia magnética de columna lumbosacra. Acta Médica Grupo Ángeles. 2012;1(3):146-7.

15. Duffoo-Olvera M, Dufoo-Villegas M, Preciado-Salgado MA. Criterios de tratamiento de la hernia discal aislada y de hernias discales múltiples. Ortho-tips. 2005:1(2):77-93.

16. Fardon DF, Milette PC; Combined Task Forces of the North American Spine Society, American Society of Spine Radiology, and American Society of Neuroradiology. Nomenclature and classification of lumbar disc pathology. Recommendations of the Combined task Forces of the North American Spine Society, American Society of Spine Radiology, and American Society of Neuroradiology. Spine (Phila Pa 1976). 2001 ;26(5):E93-E113.

17. Instituto Nacional de Estadísticay Geografía (INEGI). Población total por entidad federativa: Censode Población y Vivienda 2010. Jalisco, México. 2011. Disponible en: http://www.inegi.org.mx/est/contenidos/proyectos/inp/indicelineal.aspx?nomArchivo= BMC_10020000011400000_lidvt4f2lbb4eu5atfw5kkk1.xml\&Titulo=Poblaci\%C3\%B3n totalokrevgems

18. Jiménez-Avila JM, Alvarez-Garnier JC, Bitar-Alatorre WE. Direct cost of complete cervical spinal cord injury. Acta Ortop Mex. 2012;26(1):10-4. 